\title{
Pengelolaan Keuangan Berbasis Web PT. Mutualplus Global Resources Cabang Pontianak Windi Irmayani $^{1}$, Yulia ${ }^{2}$, Rahayu Dwi Utami ${ }^{3}$
}

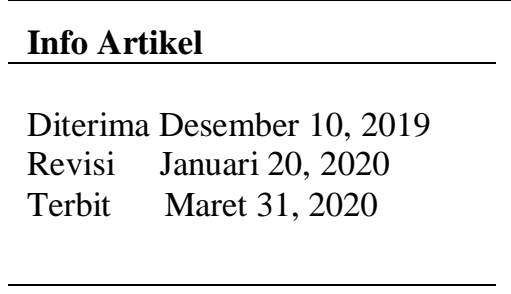

\section{Keywords:}

Financial Management Accounting Information System

\begin{abstract}
PT. Mutualplus Global Resources Pontianak Sub Division consultant outsourcing company. According to the result of analysis found that processing the financial reports still using bookkeeping technique which is rewriting of notes to ledger and then converted to MS. Excel to be produced as financial reports, so the generated reports were late and not accurate. This Final Project contained about the research to solved the problems at PT. Mutualplus Global Resources by building the web-based of financial management accounting information system using waterfall model as software development method which consists of software requirement analysis, design, code generation and testing. The system is built to provides facilities for Admin \& Finance and Directors. Admin and Finance can manage account data, cash receipt data, cash disbursement data, access general journals, ledgers, balance sheet reports, cash receipt reports, cash disbursement reports, income statements and statement of capital reports. Meanwhile, the Director can manage user data, access general journal reports, general ledger reports, balance sheet reports, cash receipts reports, cash disbursement reports, income statements and statement of capital reports. This system is expected to improve financial management performance at PT. Mutualplus Global Resources Pontianak sub Division.
\end{abstract}

\section{Identitas Penulis:}

Windi Irmayani ${ }^{1}$, Yulia ${ }^{2}$, Rahayu Dwi Utami ${ }^{3}$

Universitas Bina Sarana Informatika Program Studi Sistem Informasi Akuntansi Kampus Pontianak

Jalan Abdurrahman Saleh no. 18 A Pontianak

Email: windi.wnr@bsi.ac.id ${ }^{\mathbf{1}}$, yulia.yla@bsi.ac.id ${ }^{\mathbf{2}}$, $\underline{\text { rahayudwiutami88@gmail.com }}^{\mathbf{3}}$

\section{PENDAHULUAN}

Salah satu kebutuhan yang sangat besar akan teknologi informasi sekarang ini adalah kebutuhan akan sistem informasi. Berkembangnya teknologi informasi dan sistem informasi yang demikian pesat di era sekarang ini telah membuat hampir semua aspek kehidupan tidak dapat terhindar dari penggunaan perangkat komputer [1].

Penggunaan aplikasi sebagai alat bantu dalam pengambilan keputusan dan aplikasi tersebut digunakan sebagai bahan untuk memperoleh hasil pencarian dari suatu pokok permasalahan. Diharapkan hasilnya akan memberikan solusi serta mengambil keputusan dengan tepat. Penerapan sistem informasi memberikan fasilitas seperti perolehan informasi yang cepat dan tepat pada saat dibutuhkan. Informasi dirancang untuk keperluan pengolahan data dengan penerapan teknologi komputer sehingga seluruh proses kegiatan dapat dikelola menjadi informasi yang bermanfaat [2].

Jika data yang diolah dengan sistem pembukuan (bookkeeping's system) jumlahnya sangat banyak, dapat mengakibatkan keterlambatan dalam penyajian informasi atau informasi yang disajikan tidak akurat. Keterlambatan dan ketidakakuratan informasi yang diperlukan dapat menyebabkan tertundanya pencapaian tujuan perusahaan dan akhirnya dapat mengganggu perkembangan perusahaan. Hal ini membuktikan bahwa pengolahan data dengan sistem pembukuan (bookkeeping's system) memiliki banyak kelemahan. Maka dari itu, diperlukan suatu pengolahan data yang lebih canggih untuk merealisasikan perolehan informasi yang handal, cepat, akurat, dan tepat waktu dengan cara beralih ke sistem yang terkomputerisasi. 
PT. Mutualplus Global Resources di Pontianak adalah perusahaan bidang konsultan sumber daya manusia (SDM), jasa rekrutmen dan jasa psikotes. Pengelolaan transaksi seperti pengolahan data kas, penerimaan, dan pengeluaran kas dicatat ke dalam nota-nota transaksi yang kemudian disalin menggunakan Ms. Excel. Untuk menghasilkan laporan keuangan memerlukan waktu yang lama, dikarenakan bagian keuangan harus merekapitulasi satu per satu transaksi penerimaan dan pengeluaran untuk dijadikan laporan laba rugi, laporan perubahan modal, neraca dan neraca lajur. Keterlambatan dalam penyajian laporan ini berpengaruh pada proses pengambilan keputusan khususnya yang berkaitan dengan masalah keuangan. Selain itu, sering terjadi selisih atau kesalahan dalam pengalokasian transaksi oleh bagian keuangan. Alat yang digunakan untuk menganalisa laporan keuangan juga belum mendukung secara maksimal dalam menilai kinerja keuangan walaupun sudah dibantu menggunakan Ms. Excel dalam perhitungan dan penentuan keputusan. Maka dari itu diperlukan sebuah sistem informasi akuntansi laporan keuangan pada PT. MUTUALPLUS GLOBAL RESOURCES di Pontianak agar dapat mengelola data-data transaksi penerimaan dan pengeluaran yang ada menjadi laporan keuangan dengan cepat dan akurat.

\section{METODE}

Untuk mendukung metode penelitian ini, digunakan teknik pengumpulan data yang terdiri dari observasi, wawancara dan studi pustaka. Untuk pengembangan software digunakan metode pengembangan perangkat lunak dengan model air terjun (waterfall).

\subsection{Teknik Pengumpulan Data}

Teknik pengumpulan data berfungsi sebagai cara untuk mengumpulkan data-data yang berkaitan dengan penulisan. Teknik pengumpulan data yang digunakan, terdiri dari observasi, wawancara dan studi pustaka. Adapun penjelasan dari teknik pengumpulan data yang digunakan, diuraikan sebagai berikut:

1. Observasi

Penulis melakukan pengamatan-pengamatan langsung terhadap kegiatan yang berhubungan dengan masalah yang diambil untuk mengamati secara langsung proses pengolahan laporan keuangan dimulai dari pengolahan pengolahan jurnal umum, buku besar, neraca saldo, laporan laba rugi, laporan perubahan modal dan neraca lajur.

2. Wawancara

Untuk mendapatkan informasi secara lengkap maka penulis melakukan tanya jawab mengenai semua kegiatan yang berhubungan dengan pengolahan laporan keuangan dengan bapak Hiskia Natalian Budi Utomo selaku Kepala Cabang yang bertanggung jawab pada PT. Mutualplus Global Resources di Pontianak.

3. Studi Pustaka

Studi pustaka digunakan untuk mendukung penulisan jurnal ini landasan teori diambil dari referensireferensi dari buku dan jurnal peneliti terdahulu.

\subsection{Metode Pengembangan Software}

Metode pengembangan software yang digunakan dalam melakukan penelitian ini menggunakan adalah model waterfall. Model waterfall adalah "metode air terjun menyediakan pendekatan alur hidup perangkat lunak secara sekuensial atau terurut dimulai dari analisa, desain, pengkodean, pengujian, dan pendukung (support)" [3]. Metode pengembangan software dengan model waterfall ini dibagi menjadi lima (5) tahapan terdiri dari:

1. Analisis kebutuhan perangkat lunak

Dalam tahap pertama perlu menganalisa kebutuhan perangkat lunak yang akan dibuat. Untuk itu perlu diketahui permasalahan yang dialami oleh perusahaan dalam pengelolaan keuangan. Lalu dibuatlah analisa kebutuhan software.

2. Desain

Dalam tahapan desain ini, penulis membuat rancangan basis data, pemodelan rancangan menggunakan unified modeling language (UML), perancangan dan perancangan tampilan antar muka.

3. Pembuatan Kode Program

Pengkodean (coding) program menggunakan sublime text sebagai web editor bahasa pemrograman hypertext preprocessor (PHP) dan hypertext markup language (HTML) berdasarkan logika yang dirancang pada tahapan desain.

4. Pengujian

Tahapan pengujian menentukan apakah sistem atau perangkat lunak yang telah dibuat sudah sesuai dengan kebutuhan pengguna atau belum dengan metode black box testing sebagai media pengujian.

\section{HASIL}




\subsection{Analisis Kebutuhan Software}

Setelah menguraikan tinjauan kasus, tahapan berikutnya adalah menganalisis kebutuhan perangkat lunak (software). Analisis kebutuhan perangkat lunak ini terdiri dari tahapan analis kebutuhan pengguna, pemodelan kebutuhan pengguna menjadi use case diagram, menjelaskan kegiatan atau activity diagram untuk setiap use case dan sequence diagram untuk menjelaskan urutan interaksi antar objek.

\subsubsection{Analisa Kebutuhan Fungsional}

Tahapan analisis ini menguraikan tentang kebutuhan pengguna atau spesifikasi kebutuhan yang diperlukan dari sistem informasi pengelolaan keuangan pada PT. Mutualplus Global Resources.

A1 Skenario Kebutuhan Bagian Admin dan Keuangan
a) Login
b) Mengelola data rekening akun
c) Mengelola data penerimaan
d) Mengelola data pengeluaran
e) Mengakses laporan jurnal umum
f) Mengakses buku besar
g) Mengakses neraca saldo
h) Mengakses laporan penerimaan kas
i) Mengakses laporan pengeluaran kas
j) Mengakses laporan laba rugi
k) Mengakses laporan perubahan modal
1) Logout

A2 Skenario Kebutuhan Bagian Direktur

a) Login

b) Mengelola data pengguna aplikasi

c) Mengakses laporan jurnal umum

d) Mengakses buku besar

e) Mengakses neraca saldo

f) Mengakses laporan penerimaan kas

g) Mengakses laporan pengeluaran kas

h) Mengakses laporan laba rugi

i) Mengakses laporan perubahan modal

j) Logout

A. Kebutuhan Sistem

1) Pengguna harus melakukan login dengan cara mengisi username dan password, apabila berhasil login, maka setiap pengguna dapat mengakses sstem informasi akuntasi pengelolaan keuangan ini sesuai dengan level akses.

2) Pengguna harus melakukan logout setelah selesai menggunakan aplikasi.

3) Laporan dapat diakses atau dicari berdasarkan bulan dan tahun pencarian, laporan ini juga dapat diakses secara keseluruhan untuk setiap tahunnya.

\subsubsection{Use Case Diagram}

Kebutuhan pengguna yang telah diuraikan pada tahapan analisis kebutuhan pengguna untuk sistem informasi pengelolaan keuangan pada PT. Mutualplus Global Resources in akan dimodelkan menjadi use case diagram. 


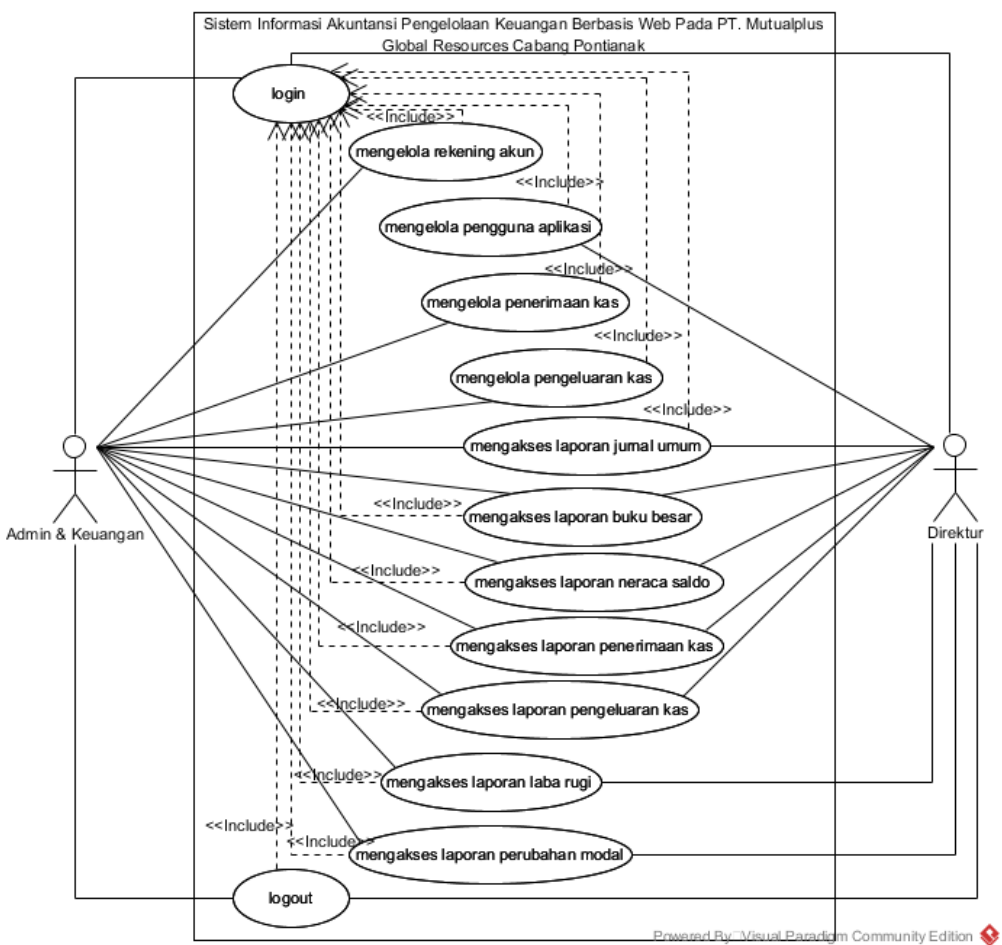

Sumber: Hasil Penelitian (2019)

Gambar 1. Rancangan Use Case Diagram

\subsubsection{User Interface}

Hasil rancangan use interface atau antarmuka dari sistem informasi akuntansi pengelolaan laporan keuangan berbasis web pada PT. Mutualplus Global Resources Cabang Pontianak ini menyediakan fasilitas kepada dua (2) level pengguna, yaitu Admin dan Keuangan dan Direktur. Adapun hasil rancangan antar muka atau user interface dapat dilihat pada halaman berikut ini.

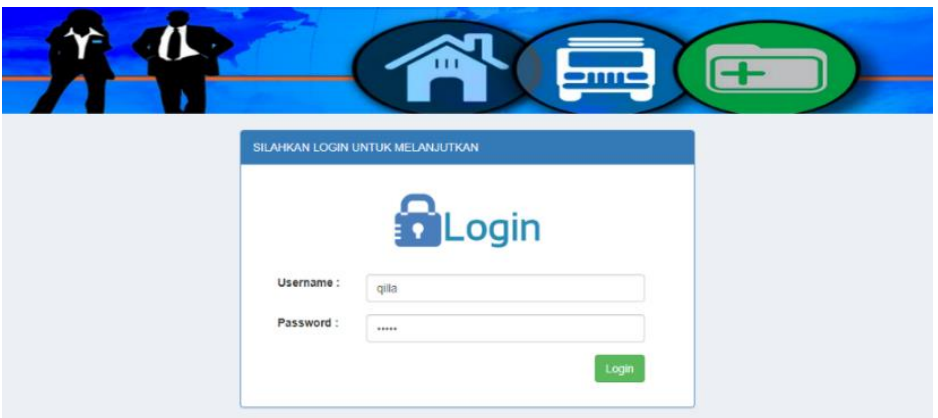

Sumber: Hasil Penelitian (2019)

Gambar 2. Tampilan Login (Admin/Direktur)

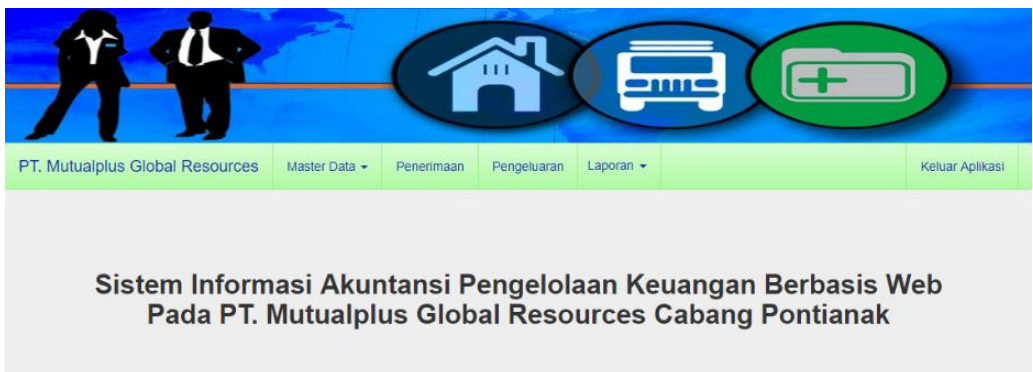

Sumber: Hasil Penelitian (2019)

Gambar 3. Tampilan Menu Utama (Admin/Direktur) 


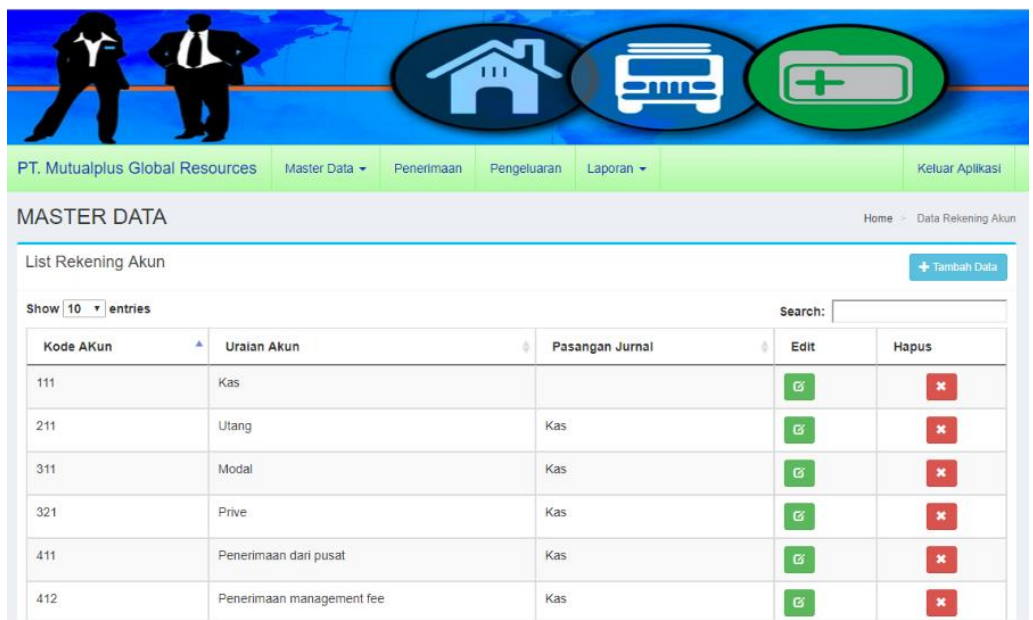

Sumber: Hasil Penelitian (2019)

Gambar 4. Tampilan Rekening Akun (Admin)

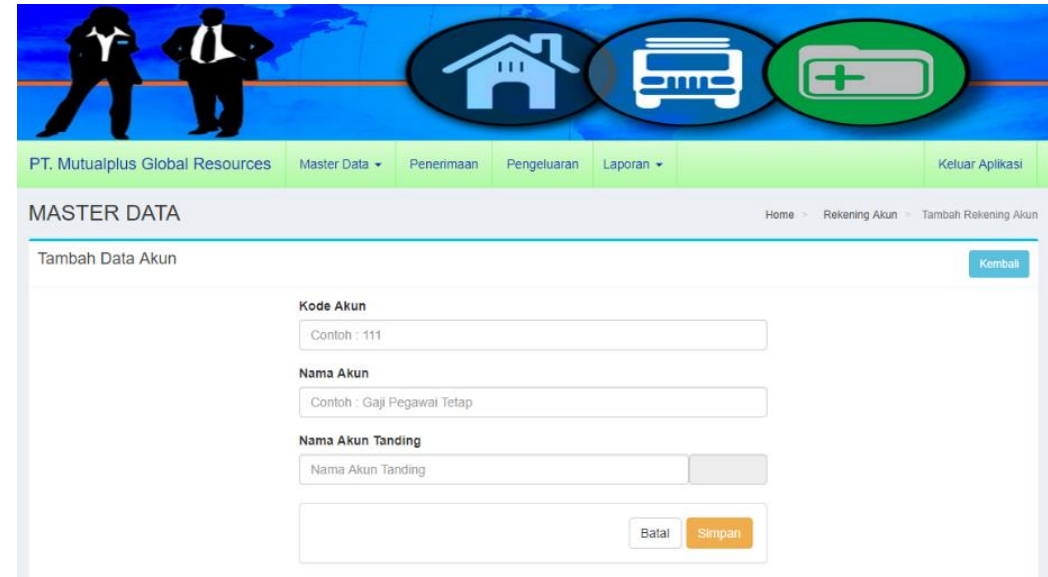

Sumber: Hasil Penelitian (2019)

Gambar 5. Tampilan Tambah Data Rekening Akun (Admin)

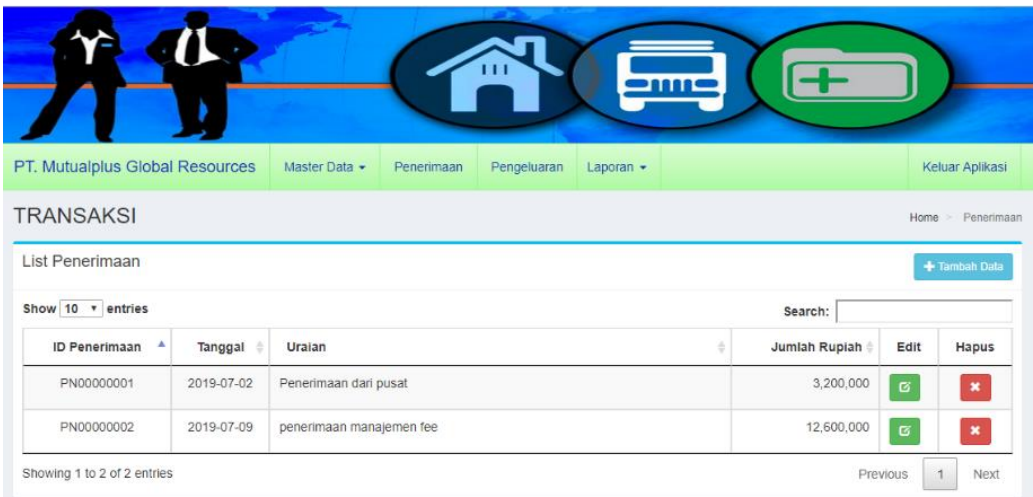

Sumber: Hasil Penelitian (2019)

Gambar 6. Tampilan Penerimaan (Admin) 


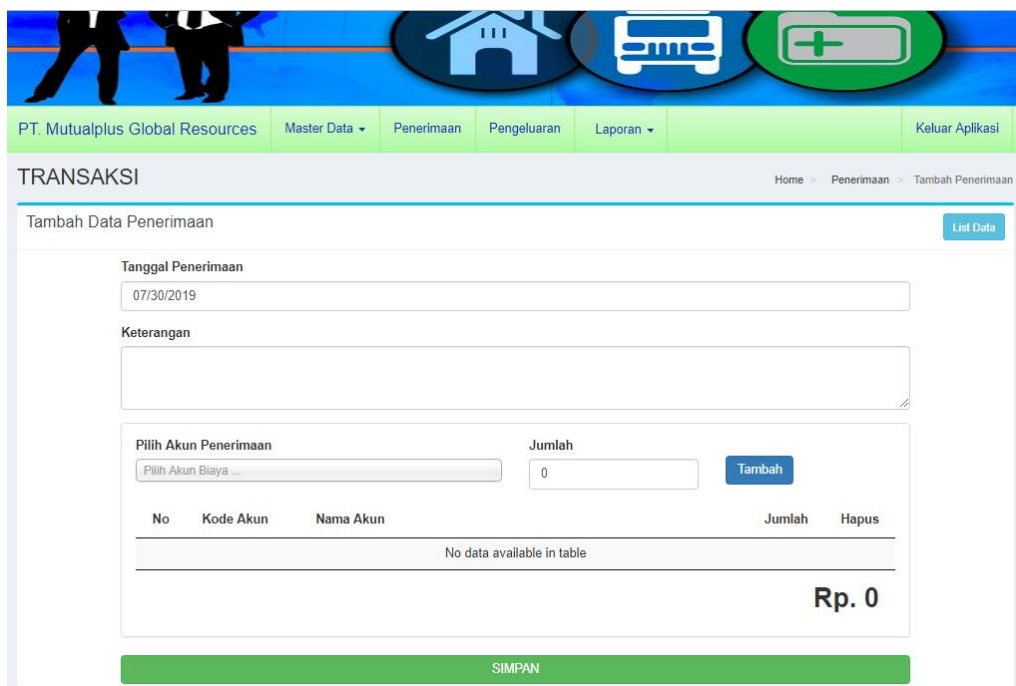

Sumber: Hasil Penelitian (2019)

Gambar 7. Tampilan Tambah Data Penerimaan (Admin)

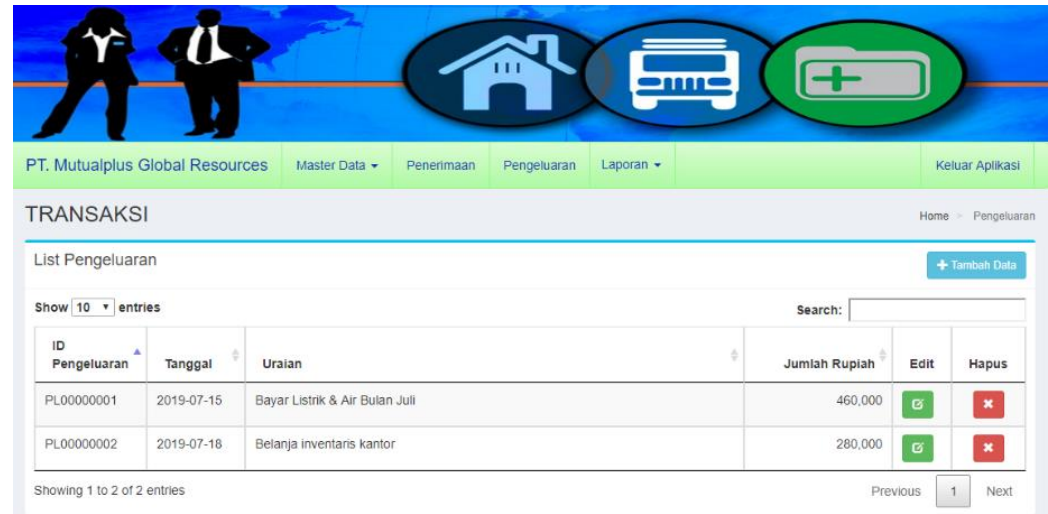

Sumber: Hasil Penelitian (2019)

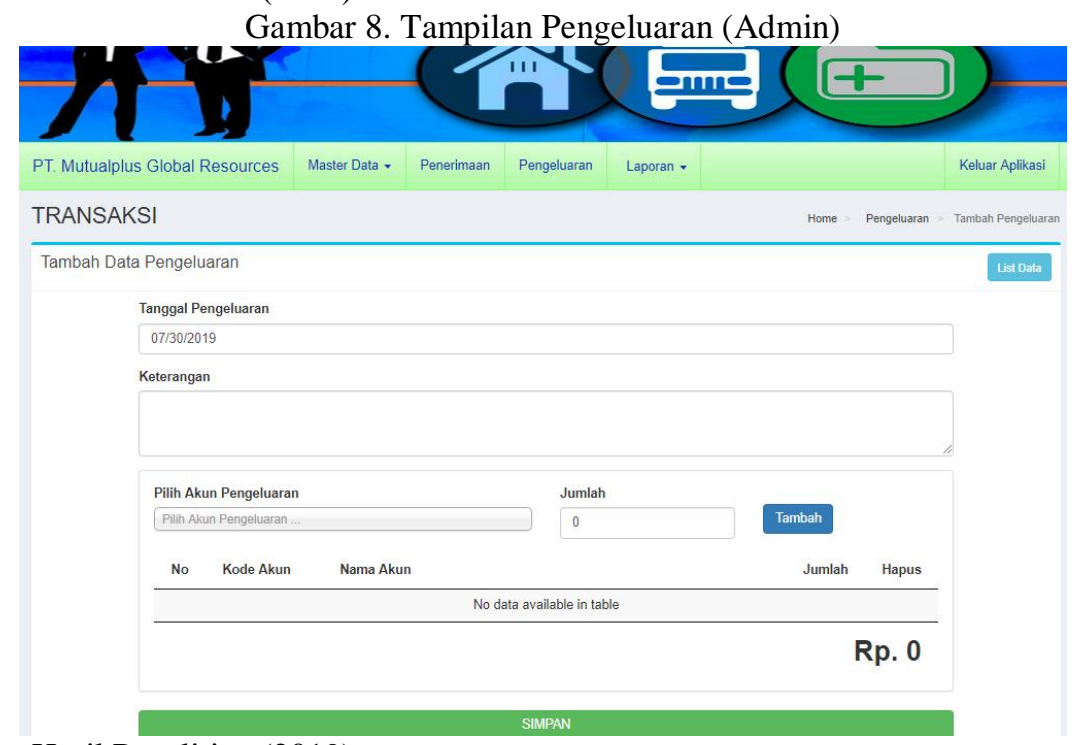

Sumber: Hasil Penelitian (2019)

Gambar 9. Tampilan Tambah Data Pengeluaran (Admin) 


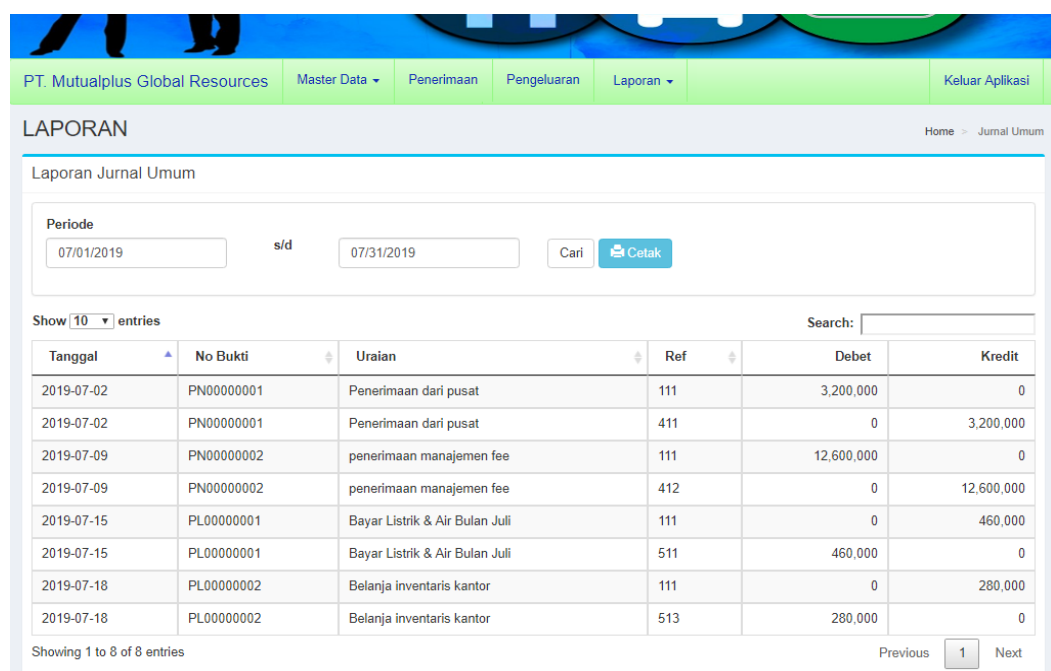

Sumber: Hasil Penelitian (2019)

Gambar 10. Tampilan Laporan Jurnal Umum (Admin/Direktur)

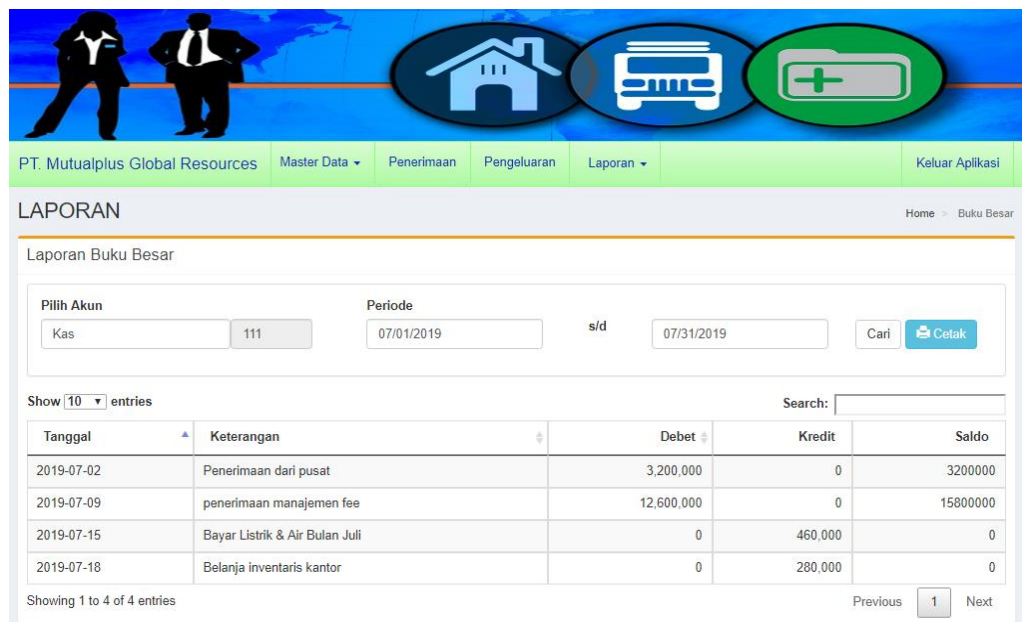

Sumber: Hasil Penelitian (2019)

Gambar 11. Tampilan Laporan Buku Besar (Admin/Direktur)

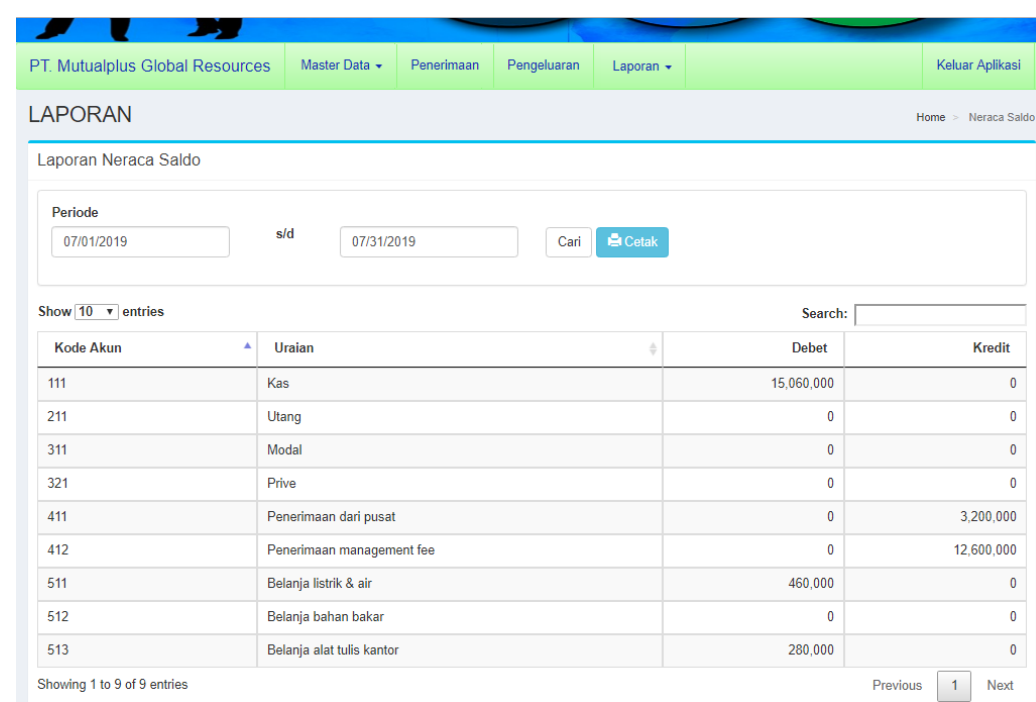

Sumber: Hasil Penelitian (2019)

Gambar 12. Tampilan Laporan Neraca Saldo (Admin/Direktur) 


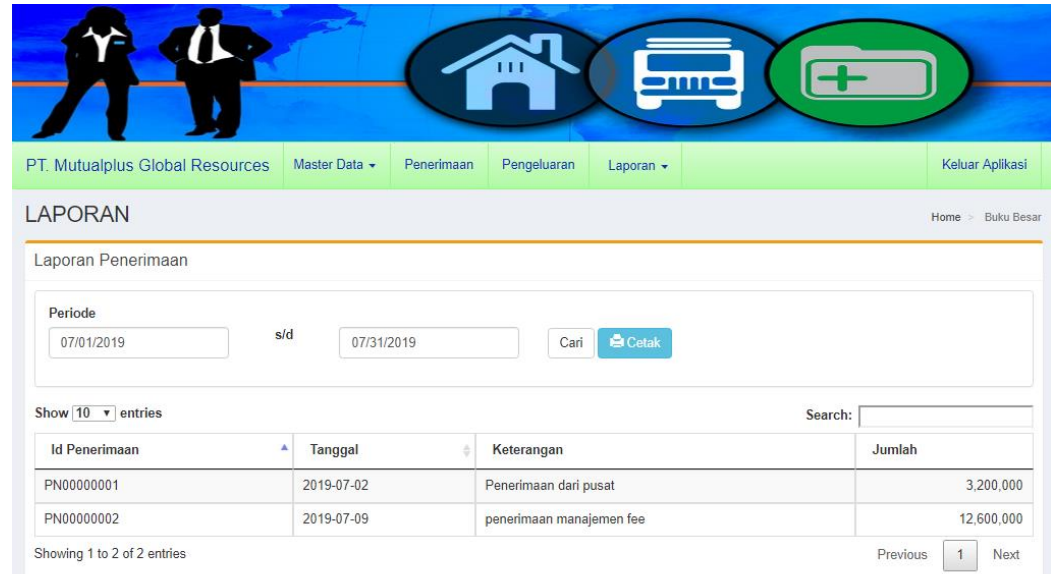

Sumber: Hasil Penelitian (2019)

Gambar 13. Tampilan Laporan Penerimaan Kas (Admin/Direktur)

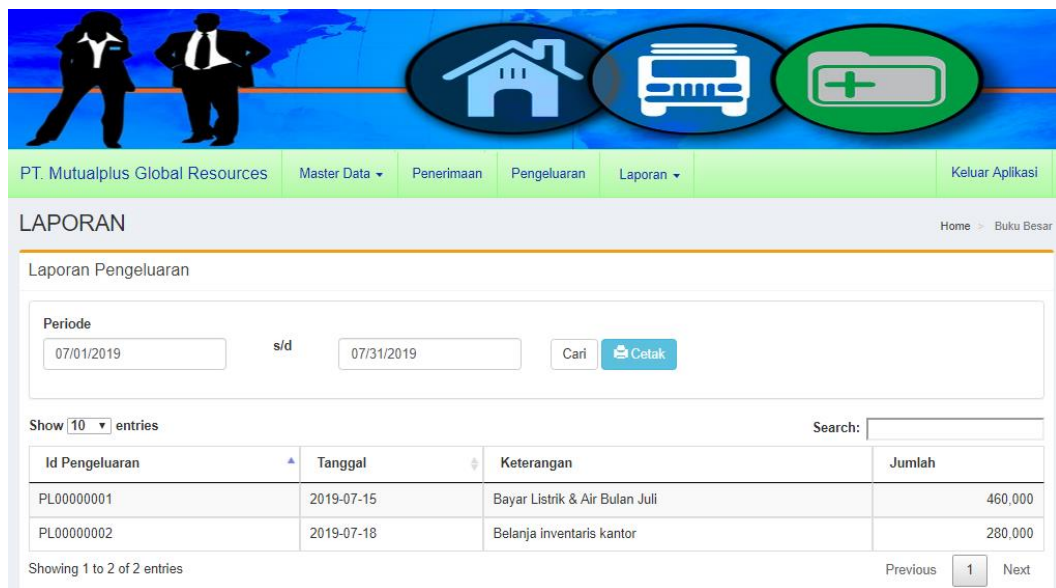

Sumber: Hasil Penelitian (2019)

Gambar 14. Tampilan Laporan Pengeluaran Kas (Admin/Direktur)

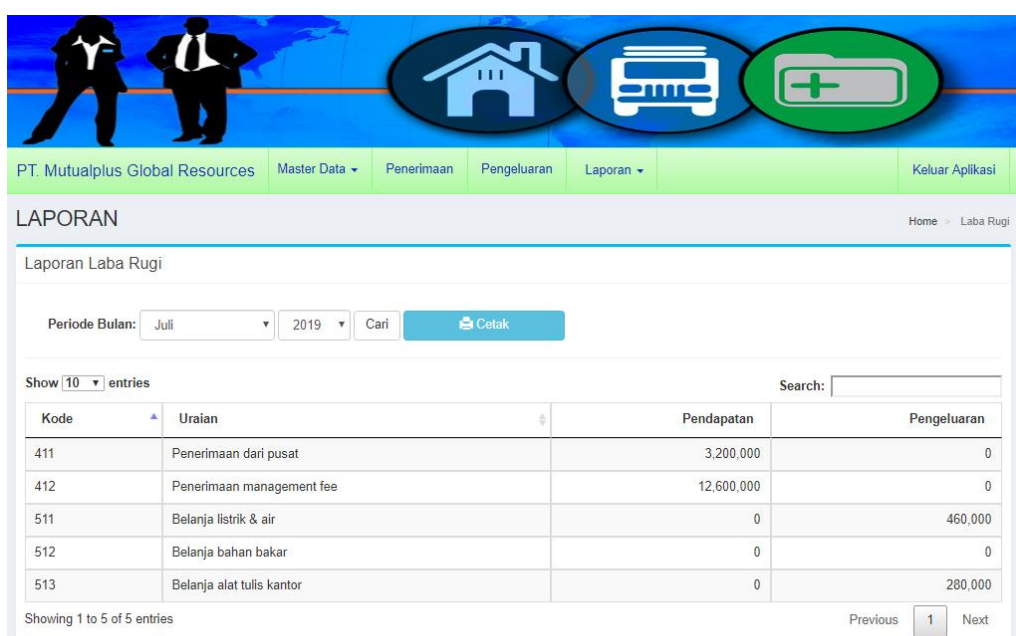

Sumber: Hasil Penelitian (2019)

Gambar 15. Tampilan Laporan Laba Rugi (Admin/Direktur) 

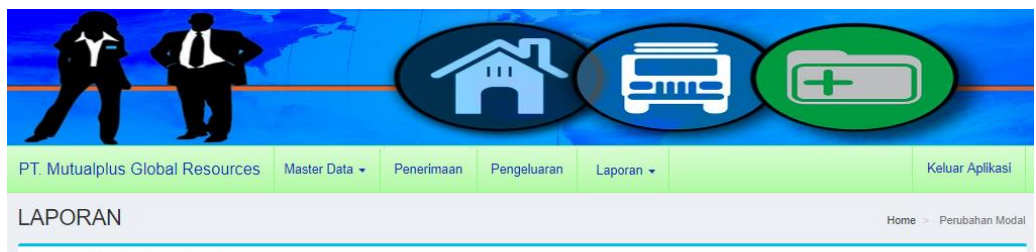

Laporan Perubahan Modal

Sumber: Hasil Penelitian (2019)

Gambar 16. Tampilan Laporan Perubahan Modal (Admin/Direktur)

\begin{tabular}{|c|c|c|c|c|c|c|c|c|}
\hline \multicolumn{2}{|c|}{ PT. Mutualplus Global Resources } & Master Data - & Laporan - & & & & \multicolumn{2}{|c|}{ Keluar Aplikasi } \\
\hline \multicolumn{4}{|c|}{ PENGATURAN } & & & \multicolumn{3}{|c|}{ Home = Data User Logit } \\
\hline \multicolumn{4}{|c|}{ List Rekening User Login } & & & \multicolumn{3}{|c|}{ + Tambah Data } \\
\hline \multicolumn{4}{|c|}{ sukses! Data Berhası Di Simpan } & & & \multicolumn{3}{|r|}{$x$} \\
\hline \multicolumn{4}{|c|}{ Show $10 \vee$ entries } & \multicolumn{4}{|c|}{ search: \lceil} & \\
\hline No 4 & Nama Lengkap & & $\Rightarrow$ User Login & & Level & $\Rightarrow$ & Edit & Hapus \\
\hline 1 & Sukri Marwan & & direktur & & Direktur & & 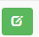 & $x$ \\
\hline 2 & Rahayu & & admin & & Admin & & 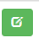 & $x$ \\
\hline 3 & rahayu dwi utami & & qilla & & Admin & & E & $x$ \\
\hline
\end{tabular}

Sumber: Hasil Penelitian (2019)

Gambar 17. Tampilan Pengguna Aplikasi (Direktur)
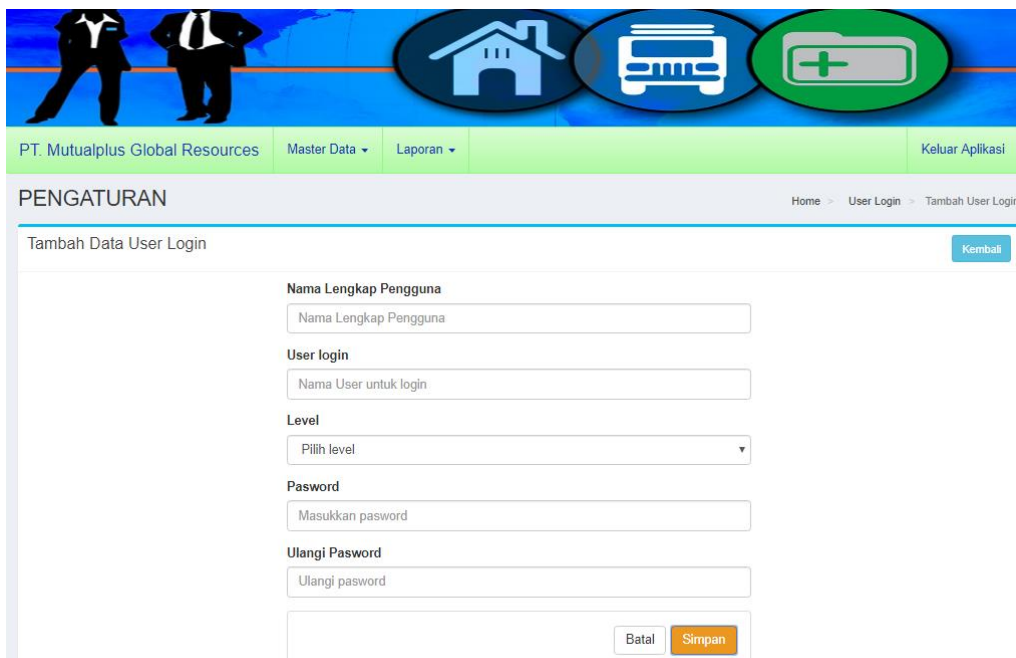

Sumber: Hasil Penelitian (2019)

Gambar 18. Tampilan Tambah Data Pengguna Aplikasi (Direktur)

\section{KESIMPULAN}

Jumlah data yang diolah sangat banyak sehingga menyebabkan pelaku pengolah data atau Admin dan Keuangan yang mengolah penerimaan dan pengeluaran kas harus merekap satu persatu transaksi kas masuk dan kas keluar yang bersumber dari surat-surat atau bukti-bukti untuk dijadikan laporan keuangan. Pengolahan data seperti ini memerlukan tenaga, waktu yang relatif lama, kesalahan dalam pengolahan data maupun keterlambatan dalam penyajian data mengenai laporan keuangan. Solusi yang dapat diterapkan oleh PT. Mutualplus Global Resources adalah menggunakan sistem informasi akuntasi pengelolaan keuangan agar dapat mengelola penerimaan dan pengeluaran kas serta menghasilkan laporan-laporan dengan standar akuntansi. 
Sistem informasi akuntansi pengelolaan keuangan yang dibuat dapat menyajikan pengolahan laporan keuangan sesuai dengan siklus akuntansi seperti jurnal umum, buku besar, neraca saldo, laporan penerimaan kas, laporan pengeluaran kas, laporan laba rugi dan laporan perubahan modal. Sistem informasi akuntansi pengelolaan keuangan yang dibangun ini menyediakan fasilitas sesuai dengan level aksesnya. Level akses pada sistem informasi akuntansi ini terdiri dari admin dan direktur. Admin dapat mengelola rekening akun, data penerimaan kas, data pengeluaran kas, mengakses jurnal umum, buku besar, neraca saldo, laporan penerimaan kas, laporan pengeluaran kas, laporan laba rugi dan laporan perubahan modal. Sedangkan direktur dapat mengelola data user, mengakses jurnal umum, buku besar, neraca saldo, laporan penerimaan kas, laporan pengeluaran kas, laporan laba rugi dan laporan perubahan modal.

\section{REFERENSI}

[1] Sholikhah, I., Sairan, M., dan Syamsiah, N. O. Aplikasi Pembelian Dan Penjualan Barang Dagang Pada CV Gemilang Muliatama Cikarang. Jurnal Teknik Komputer AMIK BSI, 3, 16-23. 2017.

[2] Firmansyah, Y., \& Udi. Penerapan Metode SDLC Waterfall Dalam Pembuatan Sistem Informasi Akademik Berbasis Web Studi Kasus Pondok Pesantren Al-Habi Sholeh Kabupaten Kubu Raya, Kalimantan Barat. Jurnal Teknologi \& Manajemen Informatika, 4, 185-191. 2018.

[3] Sukamto, R. A., \& Shalahuddin, M. Kolaborasi Rekayasa Perangkat Lunak Terstruktur dan Berorientasi Objek. Bandung: Informatika. 2015. 